\title{
Conceptualising Mass Atrocity Prevention, Nonviolent Resistance, and Politically Feasible Alternatives
}

\author{
Eamon Aloyo \\ Leiden University, Faculty of Governance and Global Affairs, \\ The Institute of Security and Global Affairs, the Netherlands \\ e.t.aloyo@fgga.leidenuniv.nl
}

\begin{abstract}
I present an account of mass atrocity prevention based on just war theory precepts. This account entails comparisons among policy options and requires selecting the politically feasible option that has the greatest chance of avoiding atrocities. Adopting such an account of atrocity prevention highlights problems in influential mass atrocity prevention policy reports in that they fail to seriously consider nonviolent civil resistance as a mass atrocity prevention tool. Given that sometimes actors may be unwilling to live under the status quo, and agitate for reform by violent or nonviolent means, nonviolence is generally the preferable policy option. This is because under realistic scenarios, the empirical evidence generally indicates that nonviolent means are more likely to achieve positive outcomes across a range of indicators than violent ones. I illustrate my argument by applying it to strategies for democratisation, and rebut objections. Yet, nonviolent civil resistance is risky, and so revolutionary leaders and their supporters should weigh carefully the chances of success and the trade-offs of nonviolent resistance.
\end{abstract}

\section{Keywords}

Nonviolent resistance - mass atrocity prevention - responsibility to protect $(\mathrm{R} 2 \mathrm{P})$ democratisation - revolution - just war theory

The questions I consider in this paper are how mass atrocity prevention should be conceived and what role, if any, nonviolent resistance has in mass atrocity

(C) ALOYO, 2018 | DOI 10.1163/1875984X-01004005

This is an open access article distributed under the terms of the prevailing CC-BY-NC license at the time of publication. 
prevention. I contend that those focused on atrocity prevention as well as those striving for other ends such as democratic government should consider and use nonviolent resistance under certain circumstances because it is preferable to other policy options when assessed according to the probabilities of several outcomes, including the likelihood of avoiding atrocities. By offering an account of mass atrocity prevention that accepts political realities and requires comparison among politically feasible alternative options, my argument has important implications for how mass atrocity prevention should be conceived of and executed by both domestic and international actors.

As I discuss below, a number of mainstream mass atrocity prevention documents fail to seriously consider nonviolent mass movements as a mass atrocity prevention tool, or only mention the risks of nonviolent mass movements without taking the additional key step of comparing the risks of nonviolent means to violent ones. ${ }^{1}$ At least since the authors of the ICIss report wrote that ' $[\mathrm{p}]$ revention is the single most important dimension of the responsibility to protect,', ${ }^{2}$ prevention has been repeatedly emphasised as the preferable way to deal with potential atrocities, for obvious reasons. In recent years, there has been a renewed push for prevention initiatives by the UN, regional organisations, and states. ${ }^{3}$ This paper aims to contribute to both the recent developments in the academic literature on atrocity prevention and the policy making process when actors are considering various means of attempting to avoid atrocities when working towards legitimate goals such as democratisation. Part of the conclusion of this paper is that the evidence suggests that nonstate actors have an important, nonviolent role to play in mass atrocity prevention.

1 Gareth Evans et al., The Responsibility to Protect: The Report of the International Commission on Intervention and State Sovereignty (Ontario, Canada: IDRC Books, 2001); Madeleine Albright and William Cohen, Preventing Genocide: A Blueprint for U.s. Policymakers (United States Holocaust Memorial Museum, 2008), http://www.ushmm.org/m/pdfs/20081124-genocide -prevention-report.pdf, accessed 1 June 2018; Ban Ki-moon, 'Implementing the Responsibility to Protect', 12 January 2009, http://www.un.org/ga/search/view_doc.asp?symbol=A/63/677, accessed 1 June 2018; United Nations, 'Framework of Analysis for Atrocity Crimes: A Tool for Prevention', 2014, http://www.un.org/en/preventgenocide/adviser/pdf/framework\%20 of\%20analysis\%2ofor\%20atrocity\%2ocrimes_en.pdf, accessed 1 June 2018.

2 Evans et al., The Responsibility to Protect, p. XI.

3 Jennifer Welsh, 'The Responsibility to Prevent: Assessing the Gap between Rhetoric and Reality', Cooperation and Conflict, 51/2: 216-32 (June 1, 2016); Serena K. Sharma and Jennifer M. Welsh (eds.), The Responsibility to Prevent: Overcoming the Challenges of Atrocity Prevention, $1^{\text {st }}$ edition (Oxford: Oxford University Press, 2015). 
The paper is organised as follows. First, I defend an account of mass atrocity prevention that draws on just war theory precepts to make comparisons among various realistic policy options that requires selecting those policies that minimise the risk of atrocities (holding other things constant). Second, I show that some influential mass atrocity prevention documents fail to present atrocity prevention in this way by either omitting, or only emphasising the risks of, nonviolent mass movements. Third, I consider and rebut several objections by showing that nonviolent methods are more likely than violent methods to meet just war theory precepts and avoid atrocities in some circumstances, and that nonviolence is not necessarily overly demanding. Throughout, I illustrate my argument with a discussion of nonviolent and violent means of attempting democratisation.

\section{Conceptualising Mass Atrocity Prevention and Just War Theory Precepts}

In this section, I argue that those seeking to prevent atrocities should use just war theory precepts in order to make politically realistic comparisons among various policy options and select the ones that are most likely to be successful while meeting other just war theory precepts. In seeking to achieve certain just causes, actors should consider whether their actions are likely to meet widely accepted moral principles. In deciding whether the use of force is permissible and preferable to alterative options, there are several just war theory precepts that are relevant here. These include just cause, necessity, proportionality, and reasonable chance of success. Each is a rich concept that, for reasons of space, I can only briefly describe here. A just cause is a goal that is a weighty moral good. Just war theorists include the defence of innocents from atrocities and national self-defence as quintessential just causes for war. Another just cause for the use of force that John Locke to present day just war theorists countenance is resistance against an unjust government that persistently violates important individual rights. ${ }^{4}$ Although there are various accounts of necessity, which is sometimes called last resort in its ad bellum form, ${ }^{5}$ it roughly

4 John Locke, Two Treatises of Government, 3rd ed. (Cambridge: Cambridge University Press, 1689 [1988]), para. 225; Allen Buchanan, 'The Ethics of Revolution and Its Implications for the Ethics of Intervention', Philosophy \& Public Affairs, 41/4: 291-323 (2013); Christopher J. Finlay, Terrorism and the Right to Resist: A Theory of Just Revolutionary War (Cambridge: Cambridge University Press, 2015).

5 Eamon Aloyo, 'Just War Theory and the Last of Last Resort', Ethics \& International Affairs, 29/2: 187-201 (2015), pp. 191-192. 
holds that the option that is likely to harm the fewest innocent people must be selected. ${ }^{6}$ Proportionality requires that the expected harms to innocents from a given policy must be less than the goods of achieving the same goal. ${ }^{7}$ Because war causes great harms to people, destroys property, and damages the environment, many just war theorists believe that there must be some reasonable chance that the use of force will achieve a just cause. Generally, just cause, necessity, and proportionality are necessary conditions for the use of force to be permissible.

These principles are useful in mass atrocity prevention work for two reasons. First, they outline some of the main relevant moral considerations, such as harms to innocents. Second, they require a comparative analysis among various policy options. This latter point is important because mass atrocity prevention tools include a wide range of nonviolent and violent means. What, then, is mass atrocity prevention? This may seem too obvious to merit discussion, but it is worth a brief explanation for reasons that will become clear. Atrocity prevention entails enacting policies by states domestically, international actors including foreign states and international organisations, and nonstate actors that are reasonably expected to decrease the risk of atrocities compared with other politically feasible options. This consists of two components. One requires using available evidence to assess which policies are most likely to prevent atrocities. Such analysis should rely on empirical evidence to assess overall risks and the chance of success of various policy options, and scrutiny of the specific case in question in order to assess how various policy options are likely to impact the specific situation. Second, it requires comparing all pertinent permutations of various options. It is insufficient, for instance, to simply compare doing nothing with a military intervention. Finally, the analysis should account for political constraints, especially what other actors are likely to do in response to various policies.

Determining which policies are preferable can be accomplished by selecting the policy that will likely result in the lowest risk of atrocity, based on severe harms to innocents. Following Jeff McMahan, I define innocents as individuals who are in no way liable to defensive harm, and by liable to defensive harm I mean someone has forfeited her right against being physically attacked. ${ }^{8}$ First, actors should weigh competing options for achieving their goals, including nonviolent and violent methods, with likely harms to innocents of each option as a key variable. Second, actors should select the option with what will

6 Seth Lazar, 'Necessity in Self-Defense and War', Philosophy \& Public Affairs, 40/1: 3-44 (2012).

7 Thomas Hurka, 'Proportionality in the Morality of War', Philosophy \& Public Affairs, 33/1: 34-66 (2005).

8 Jeff McMahan, Killing in War, 1st ed. (Oxford: Oxford University Press, 2009), p. 8. 
likely be the best overall outcome, including refraining from any (violent or nonviolent) actions. As I discuss further below, this does not definitively settle proportionality calculations, because some goods are difficult (and perhaps impossible) to compare, ${ }^{9}$ such as democracy and number of lives of innocents lost, but nonetheless it provides a rough guideline.

Finally, mass atrocity prevention should entail trying to prevent the worst sorts of atrocities. Not all atrocities are morally equivalent. For instance, although both the murder of 50,000 and 8 million innocent civilians could constitute genocide, the latter is far worse because of the far larger number of innocent people killed, holding all else constant. Of course, mass atrocity prevention strategies should aim at preventing all atrocities, but, to the extent possible, they should also aim at preventing the worst sorts of atrocities.

\section{Nonviolent Resistance in Key Mass Atrocity Prevention Documents}

Although the ICIss report discusses widely accepted just war theory precepts that should act as guidelines for how to implement military measures, ${ }^{10}$ part of the problem of some key mass atrocity prevention documents is that the authors seem to fail to make comparisons of the probabilities of atrocities occurring among various ways to achieve a just cause. One way they do this is by only emphasising the risks of nonviolent and violent actions without considering the relative risks between the two options. In this section, I discuss how influential policy documents portray the role of nonviolent mass movements. In the section that follows I show that even if nonviolent mass movements increase the risk of mass atrocities compared with business as usual, they may still be the preferable policy option compared with violent options because violent options generally increase the risk of atrocities even more than nonviolent ones, and sometimes revolutionary groups are unwilling to back down.

Mass atrocity prevention has become an important aim of some governments, international organisations, and civil society actors. In 2005, for instance, governments agreed to the World Summit Outcome Document, which included governments accepting the responsibility to prevent genocide, crimes against humanity, war crimes, and ethnic cleansing..1 Governments have

9 David Rodin, War and Self-Defense (Oxford: Oxford University Press, 2002), p. 115 .

10 Evans et al., The Responsibility to Protect, pp. 31-37.

11 United Nations, 'World Summit Outcome Document', 2005, paras. 138-139, http://daccess -dds-ny.un.org/doc/UNDOC/GEN/No5/487/6o/PDF/No54876o.PDF?OpenElement, accessed 1 June 2018. 
established a variety of policy tools aimed at atrocity prevention, including diplomacy, foreign aid, various types of sanctions, travel bans, arms embargos, preventive deployment of peacekeepers, and armed humanitarian intervention, among others. Learning from the failures of the international community in the Balkans and Rwanda in the 199os, a group of distinguished international experts developed the idea of the responsibility to protect (R2P) under Canadian leadership in 2001. ${ }^{12}$ A number of countries have established domestic mechanisms to address atrocity prevention, such as President Barak Obama's Atrocities Prevention Board, which he created in 2012 under the leadership of Samantha Power. ${ }^{13}$ The UN Secretary General appointed the first Special Advisor for the Prevention of Genocide in 2004 and the first Special Advisor for Responsibility to Protect in 2008. NGOs and centres such as the Global Centre for R2P, The Asia-Pacific Centre for R2P, The European Centre for R2P, and the Aegis Trust have mandates focused on mass atrocity prevention.

Yet key atrocity prevention documents have only briefly mentioned nonviolent resistance, omitted substantive discussion it as a means of atrocity prevention (one exception is James Pattison's work on civilian peacekeepers), ${ }^{14}$ or only mentioned the risks of mass nonviolent resistance. This is somewhat surprising for two reasons. First, nonviolent methods are generally preferable to violent ones. Second, even if nonviolent movements might increase the risks of harms to some innocent people, policy makers should still consider these approaches if the only other viable policy options are likely to result in greater numbers of harms to innocents.

Some of the most important recent policy documents related to the prevention of mass atrocities and the R2P that I will briefly discuss to illustrate my point include the (2001) report of the 'International Commission on Intervention and State Sovereignty' (ICISS), Albright and Cohen's (2008) 'Preventing Genocide: A Blueprint for U.s. Policymakers' (known as GPTF), the (2009) UN Secretary General Report on R2P that lays out the idea of three 'pillars' of R2P,

12 Evans et al., The Responsibility to Protect.

13 Barack Obama, 'Presidential Study Directive on Mass Atrocities (PSD 10)', 4 August 2011, http://www.whitehouse.gov/the-press-office/2011/08/04/presidential-study-directive -mass-atrocities, accessed 1 June 2018; Tessa Alleblas, Eamon Aloyo, Sarah Brockmeier, Philipp Rotmann, Jon Western. In The Shadow of Syria: Assessing the Obama Administration's Efforts on Mass Atrocity Prevention (The Hague Institute for Global Justice, April 2017), http://www.thehagueinstituteforglobaljustice.org/wp-content/uploads/2017/05/ In-the-Shadow-of-Syria-final-1.pdf, accessed 1 June 2018.

14 James Pattison, 'Unarmed Bodyguards to the Rescue? The Ethics of Nonviolent Intervention' in Michael L. Gross and Tamar Meisels (eds.), Soft War: The Ethics of Unarmed Conflict, (Cambridge: Cambridge University Press, 2017), pp. 134-51. 
and the (2014) UN 'Framework of Analysis for Atrocity Crimes'. I also include an important overview of atrocity prevention by Scott Strauss. There are of course more mass atrocity prevention and R2P policy documents, including other reports by the UN Secretary General on R2P. But the documents on which I will focus are well-respected, influential, and representative of mainstream R2P and mass atrocity prevention policy debates. My point in reviewing these documents is not to contest that nonviolent resistance may increase the chance of atrocities, the empirics of which I discuss below. Rather, it is to show that staple mass atrocity prevention documents generally only emphasise the risks of atrocities from nonviolent resistance, whereas comparing the likelihood of atrocities of various policy options is the preferable means to assess various atrocity prevention strategies.

The 2001 ICISS report originates the concept of R2 P. Its authors list four categories of tools relevant for mass atrocity prevention, only one of which permits violence. The types of tools they identify include diplomatic or political, economic, legal, and military means. ${ }^{15}$ They also differentiate root and proximate prevention actions. In a discussion of the root cause prevention measures, the ICISS commissioners mention 'democratic institution and capacity building', but do not discuss theories of democratisation..$^{16}$ They emphasise the importance of prevention ${ }^{17}$ and nonviolent options, ${ }^{18}$ but they fail to mention the role mass nonviolent movements can have in achieving these goals.

In contrast, Albright and Cohen's influential 2008 report briefly mentions nonviolent protests. Citing Barbara Harff's 2003 article $^{19}$ and 'subsequent analysis of mass killing by the PITF' (Political Instability Task Force), they claim that nonviolent protests increase the risk of genocide. ${ }^{20}$ Harff studies the risk factors for the onset of genocide and political mass murder. The independent variable that comes closest to nonviolent protest is what Harff calls 'political upheaval'. ${ }^{21}$ She defines this 'as an abrupt change in the political community caused by the formation of a state or regime through violent conflict, redrawing of state boundaries, or defeat in international war'.22 This variable includes at least two forms of violence, civil and international war, undermining the

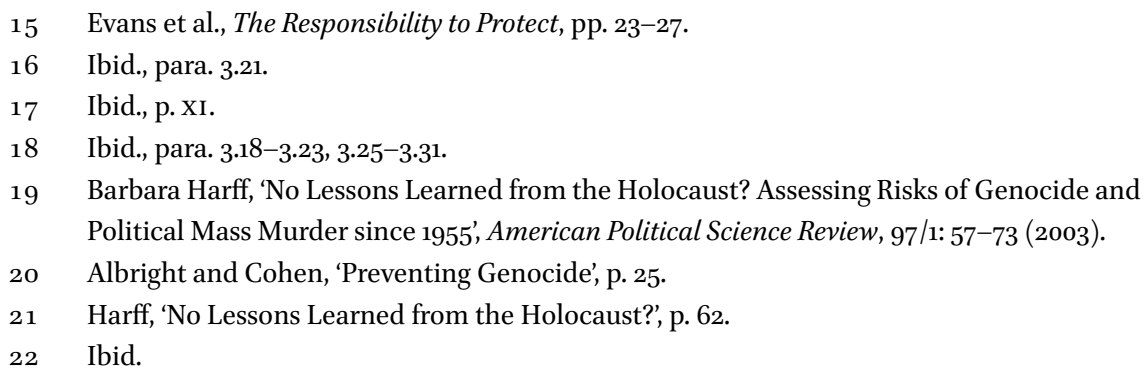


claim in the GPTF. This leaves Albright and Cohen's team subsequent analysis as the source for this claim. Because the authors of the Albright and Cohen report provide no further detail on how they conducted this analysis, there is no way to further assess their claim. Although they do not cite it (for it was published after the GPTF report), an influential article by PITF group is then a logical place to look. ${ }^{23}$ The authors of that article include a variable called 'adverse regime change', but in this measure they exclude peaceful (as defined as less than 1,00o deaths in one year) adverse regime changes that resulted in democracies ${ }^{24}$ and refer back to the 2003 paper by Harff for the onset of genocide and politicide. ${ }^{25}$ They do not provide comparisons of the relative probability between violent and nonviolent actions that may increase the risk of atrocities.

In 2009, the UN Secretary-General released a seminal report on R2P. In it, he enumerates the conditions under which states and the international community have various responsibilities under R2 P. The Secretary-General argues that states have the primary responsibility to protect their populations (Pillar One), the international community has the responsibility to assist states (with their consent) in upholding their responsibilities under R2P (Pillar Two), and only when states are manifestly failing to uphold their responsibilities can the international community use coercive measures including but not limited to the use of force (Pillar Three). The report mentions the role nonstate actors, including civil society, business, and individuals, can play in R2P. ${ }^{26}$ Given the consensus that R2P focuses on states, it is of little surprise that in the context in which the author mentions nonstate actors in the report, he concentrates on roles of civil society other than replacing state leaders. For instance, he discusses the role of activists in the us attempting to influence policy towards Sudan regarding the genocide in Darfur, but never mentions a group like Otpor, which was a central factor in ending Milosevic's rule. ${ }^{27}$

The authors of the 2014 UN Framework of Analysis for Atrocity Crimes briefly mention mass protests, but they include it only as a risk factor. Under risk factor 1.10, they write that 'social instability caused by resistance to or mass protests against State authority or policies' increases the chances of atrocity. ${ }^{28}$

23 Jack A. Goldstone, Robert H. Bates, David L. Epstein, Ted Robert Gurr, Michael B. Lustik, Monty G. Marshall, Jay Ulfelder, Mark Woodward , 'A Global Model for Forecasting Political Instability', American Journal of Political Science, 54/1: 190-208 (2010).

24 Ibid., p. 192.

25 Ibid., p. $197 \mathrm{n} 11$.

26 Ban, 'Implementing the Responsibility to Protect', paras. 11(b), 27, 59.

27 Ibid., para. 59 .

28 United Nations, 'Framework of Analysis for Atrocity Crimes: A Tool for Prevention', p. 10. 
The authors of this document provide no citation by which to evaluate this claim. The authors go on to mention that 'armed conflict has been identified as the strongest or most important contributing risk factor', but provide no systematic discussion of why nonviolent resistance may therefore be preferable to violent means of attempting to achieve a just cause. ${ }^{29}$

In 2016, Scott Straus released an important overview of mass atrocity prevention findings. ${ }^{30}$ In it, he includes violent government crackdown on protests as a triggering event that increases the risk of mass atrocities. ${ }^{31}$ Sufficiently grave widespread or systematic attacks on civilians can constitute a crime against humanity or other type of mass atrocity. In another chapter, one on preventive policy options, he does not mention nonviolent protests as a means to mitigate the risk of atrocities. ${ }^{32}$ Thus, Straus too emphasises only the risks of nonviolent action.

In sum, several influential mass atrocity prevention documents fail to seriously consider the role of nonviolent mass movements in atrocity prevention, either by omitting such an option or by only emphasising its risks. In the sections that follow, I argue such an omission and exclusive focus on potential risks is misguided, because the benefits of nonviolent movements as alternatives to violent ones sometimes outweigh the risks. But first I briefly discuss how nonviolence may be preferable to violent ways of attempting democratisation.

\section{Democratisation, and the Probability of Successes of Violent and Nonviolent Movements}

In order to provide some context under which nonviolent movements can be used as an atrocity prevention method and because it is one of the most important goals for activists living under non-democratic regimes, I will now use the struggle for democratic government as an example. An important objection to using nonviolent resistance in such circumstances is that nonviolent means may be less likely than violent means to achieve this important goal. Another objection is that nonviolent resistance is more likely to result in atrocities than violent resistance because nonviolent activists cannot defend

29 Ibid., p. 7.

30 Scott Straus, Fundamentals of Genocide and Mass Atrocity Prevention (United States Holocaust Memorial Museum, 2016), https://www.ushmm.org/m/pdfs/Fundamentals-of -Genocide-and-Mass-Atrocity-Prevention.pdf, accessed 1 June 2018.

31 Ibid., pp. 86-87.

32 Ibid., ch. 6. 
themselves. A third concern is that nonviolent resistance is overly demanding because it requires individuals to refrain from otherwise typically justified self and other defence. I will consider and rebut each objection in turn.

Democratic activists in autocratic countries first face the important question of whether to mount a sustained campaign against a ruling regime in order to try to install a democratic government. If they decide to move ahead with a democratisation campaign, they must then decide whether to resist an autocratic regime by violent or nonviolent methods (or a mixture). There are stark differences between the violent and nonviolent options. Think of the armed resistance in Syria, which started after peaceful protests did not quickly remove Assad, compared with the generally peaceful protesters in Egypt. There may be ambiguities on the margins, as relatively small-scale violence may occur by generally peaceful protesters, but there are major differences between the armed rebellion and peaceful nonviolent approaches.

The evidence suggests that nonviolent means are generally more successful than violent means of replacing leaders in general and in autocratic regimes specifically, and creating democratic government. In a seminal study, Erica Chenoweth and Maria Stephan find that from 1900 to 2006 nonviolent means were, on average, about twice as likely as violent means to successfully overthrow a government, ${ }^{33}$ even though violent campaigns were more than three times as likely to receive foreign support. ${ }^{34}$ Mauricio Celestino and Kristian Gleditsch study nonviolent and violent campaigns and find that from 1900 to 2004 nonviolent movements substantially and statistically significantly increased the chance that autocracies would transition to democracies, ${ }^{35}$ whereas violent campaigns had no effect on whether an autocratic country would transition to democracy. ${ }^{36}$ Another scholar who studies democratic transitions during the 'third wave' of democratisation, Jan Teorell, finds that from 1972-2006 nonviolent protests - but not violent conflicts-contributed to democratisation. ${ }^{37}$ Barbara Geddes, Joseph Wright, and Erica Frants released a

33 Erica Chenoweth and Maria Stephan, Why Civil Resistance Works: The Strategic Logic of Nonviolent Conflict (New York: Columbia University Press, 2011), pp. 66-67, 72-73.

34 Ibid., p. 54 .

35 Mauricio Rivera Celestino and Kristian Skrede Gleditsch, 'Fresh Carnations or All Thorn, No Rose? Nonviolent Campaigns and Transitions in Autocracies', Journal of Peace Research, 50/3: 385-400 (2013).

36 Ibid., p. 393 .

37 Jan Teorell, Determinants of Democratization: Explaining Regime Change in the World, 1972-2006 (Cambridge: Cambridge University Press, 2010), chap. 5. 
dataset in 2014 that lends preliminary evidence in support of these findings. ${ }^{38}$ They find that nonviolent campaigns are more likely than violent revolts to result in democratisation. ${ }^{39}$ Controlling for several variables, Chenoweth and Stephan find that five years after the end of a successful campaign, including revolutions, ending occupations, and secession, less than $5 \%$ of successful violent campaigns resulted in democracies, whereas $57 \%$ of successful nonviolent ones had democratic results, a greater than 10 fold difference. ${ }^{40}$ Other scholars find that a country having a nonviolent mass movement as it transitions to democracy increases the chance the country will sustain democracy ${ }^{41}$ and decreases the chance of a democratic breakdown by about $50 \%{ }^{42}$

Additionally, reformers were about twice as likely to partially achieve their goals if they used nonviolent means compared with violent ones. ${ }^{43}$ Nonviolent campaigns occurred more frequently in autocratic regimes than in democratic countries, ${ }^{44}$ and in autocracies nonviolent movements were more likely to succeed than violent rebellions. ${ }^{45}$

Some might think that nonviolent methods might be more likely to achieve positive goals compared with violent means, but it might seem that together nonviolent and violent tactics are the most likely to overthrow a government. However, pairing violence with nonviolence is no more likely to be successful than nonviolent campaigns. ${ }^{46}$ But what happens if the regime uses violence against peaceful demonstrators? Even in the face of violent crackdowns, maintaining nonviolence is still 'considerably more effective than violent resistance. 47 Protesters increase their probability of success by over $20 \%$ if they maintain nonviolence in the face of regime violence. ${ }^{48}$

38 Barbara Geddes, Joseph Wright, and Erica Frantz, 'Autocratic Breakdown and Regime Transitions: A New Data Set', Perspectives on Politics, 12/2: 313-331 (2014).

39 Ibid., p. 325 .

40 Chenoweth and Stephan, Why Civil Resistance Works, pp. 213-15.

41 Markus Bayer, Felix S. Bethke, and Daniel Lambach, 'The Democratic Dividend of Nonviolent Resistance', Journal of Peace Research 53/6: 758-71 (2016).

42 Ibid., pp. 759, 767-68.

43 Chenoweth and Stephan, Why Civil Resistance Works, pp. 72-73.

44 Ibid., pp. 66-67.

45 Ibid.

46 Erica Chenoweth and Kurt Schock, 'Do Contemporaneous Armed Challenges Affect the Outcomes of Mass Nonviolent Campaigns?', Mobilization: An International Quarterly, 20/4: 427-51 (2015).

47 Chenoweth and Stephan, Why Civil Resistance Works, p. 68.

48 Ibid., p. 51 . 
Not all revolutions succeed. Therefore, we should also consider the likely outcomes of failed violent and nonviolent revolutions. Examining violent and nonviolent campaigns in situations of revolutions, ending occupations, and secession, Chenoweth and Stephan find that countries in which a failed nonviolent campaign occurred have a greater than $33 \%$ chance of becoming democratic five years after the campaign ends, whereas failed violent campaigns have a less than $4 \%$ chance of being democratic five years later. ${ }^{49}$ Approximately the same chances hold when a country is autocratic at the end of a violent and nonviolent campaign. ${ }^{50}$

What impact do violent and nonviolent movements have on the probability of war? We know that according to various calculations over different time periods, the vast majority of atrocities occur during war. ${ }^{51}$ Avoiding civil war therefore decreases the risk of atrocities, on average. Nonviolent mass movements have irenic effects after a revolution. Chenoweth and Stephan find that after successful overthrow of governments, secession, or expulsion or occupies, nonviolent campaigns are more likely to avoid civil war than are violent rebellions. ${ }^{52}$ Specifically, a violent campaign has a $42 \%$ probability of resulting in a civil war within a decade of the campaign ending, whereas a country that has had a nonviolent campaign has a $28 \%$ chance of a civil war, a one third decrease. ${ }^{53}$ Pairing a violent campaign with a nonviolent one drastically increases the chance of civil war reoccurring too: a civil war within a decade of the end of a violent and nonviolent campaign is nearly $50 \%$ likely. ${ }^{54}$ This is broadly consistent with other scholars' findings regarding civil wars. For instance, 9 out of 10 civil wars in the 2000 s were reoccurrences of previous civil wars. ${ }^{55}$ In sum, across a range of outcomes, nonviolent movements are more likely to achieve democracy, avoid civil war, and avoid atrocities — whether or not the movements themselves are successful.

\footnotetext{
49 Ibid., p. 216.

$50 \quad$ Ibid., p. 259n.20.

51 Alex Bellamy, 'Mass Atrocities and Armed Conflict: Links, Distinctions, and Implications for the Responsibility to Prevent', Policy Analysis Brief (The Stanley Foundation, 2011), p. 2, http://www.stanleyfoundation.org/publications/pab/BellamyPAB22011.pdf; Charles H. Anderton, 'Datasets and Trends of Genocides, Mass Killings, and Other Civilian Atrocities' in Charles H. Anderton and Jurgen Brauer (eds.), Economic Aspects of Genocides, Other Mass Atrocities, and Their Prevention, (New York: Oxford University Press, 2016), p. 69.

$5^{2}$ Chenoweth and Stephan, Why Civil Resistance Works, chap. 8.

53 Ibid., p. 217 .

54 Ibid., p. 218.

55 Barbara F. Walter, 'Why Bad Governance Leads to Repeat Civil War', Journal of Conflict Resolution, 59/7: 1242-43 (2015).
} 


\section{Violent and Nonviolent Resistance, and the Probability of Atrocities}

Do nonviolent protests against a government increase the risk of repression and atrocities, and if so how does this compare to violent resistance? This concern that nonviolent resistance can increase the risk of atrocities should be taken seriously for two reasons. First, democratic activists and foreign policy makers who support their aims need to be careful that the goods they are trying to achieve do not inadvertently lead to horrific outcomes. Second, those striving for democratic government should consider likely responses from governments in deciding whether various options are likely to meet just war theory precepts. Thus, we must examine the empirical evidence of various violent and nonviolent policies and make assessments regarding probable outcomes.

There is evidence that certain types of domestic threats to a government's hold on power can increase the risk of mass atrocities by a government. ${ }^{56}$ In summarising the literature on the causes of atrocities, Straus writes that '[a]rguably, the strongest macro-level predictor of the onset of genocide and mass killing is the presence of large-scale instability'. ${ }^{57}$ But the instability he has in mind is violent instability, including civil war, violent rebellions, and coups. ${ }^{58}$ Many have found that violence against a regime increase the chances of atrocities. Benjamin Valentino, Paul Huth, and Dylan Balch-Lindsay find that mass killing increases significantly when guerrilla insurgencies pose a threat to the ruling regime. ${ }^{59}$ Gary Uzonyi finds that coups, assassinations, and guerrilla war, generally increase the risk of atrocities. ${ }^{60}$ Matthew Krain finds that civil wars are one of the biggest risk factors for atrocities. ${ }^{61}$ International war also increases the risk of atrocities. Uzonyi finds that the onset of mass killings increases by over $300 \%$ during interstate war, holding a number of other variables constant. ${ }^{62}$ In short, war and many types of violent threats to a government substantially increase the chances of atrocities. Decreasing the chance of civil war, therefore, significantly decreases the chance of atrocities.

56 Gary Uzonyi, 'Domestic Unrest, Genocide and Politicide', Political Studies, 64/2: 315-34 (2016).

57 Straus, Fundamentals of Genocide and Mass Atrocity Prevention, p. 55.

58 Ibid., pp. $55^{-57}$.

59 Benjamin Valentino, Paul Huth, and Dylan Balch-Lindsay, “Draining the Sea": Mass Killing and Guerrilla Warfare', International Organization, 58/2: 375-407 (2004).

6o Uzonyi, 'Domestic Unrest, Genocide and Politicide', pp. 323-25.

61 Matthew Krain, 'State-Sponsored Mass Murder:The Onset and Severity of Genocides and Politicides', Journal of Conflict Resolution, 41/3: 331-6o (1997).

62 Uzonyi, 'Domestic Unrest, Genocide and Politicide', p. 323. 
From a rich literature on the democratic peace, we also know that democracies rarely go to war with one another. Because nonviolent movements are more likely to achieve democratisation, they too contribute in this way to conflict prevention and therefore mass atrocity prevention.

Major nonviolent campaigns also often provoke a deadly response from governments. ${ }^{63}$ Yet scholars show that nonviolent mass protests will not similarly increase the risk of mass atrocities compared with violent threats to a regime. Some scholars have found that nonviolent protests, revolutions, and strikes do not increase the onset of highly repressive periods, whereas guerrilla war and attacks do, ${ }^{64}$ and that peaceful demonstrations ${ }^{65}$ and revolutions ${ }^{66}$ against the government do not increase the risk of genocide or politicide. One type of nonviolent protest against a government, strikes, do increase the risk of genocide (but not politicide). ${ }^{67}$ Krain has found that extra constitutional change does not increase the risk of onset of government sponsored mass murder, ${ }^{68}$ although if mass murder does occur, it increases its severity. ${ }^{69} \mathrm{He}$ does not, however, compare the effects of violent and nonviolent extra constitutional changes on the impact of chances of onset or severity of mass atrocities. Chenoweth reports that governments are about three times more likely to commit atrocities against armed groups than against nonviolent movements $(23 \%$ rather than $68 \%) . .^{70}$ In another paper, Jay Ulfelder also finds that the effect of civil resistance campaigns on atrocity onset is 'essentially zero.' ${ }^{71}$ As Chenoweth, Perkoski, and Kang write, 'a consensus finding has emerged that nonviolent dissent tends to elicit less intense government repression than violent forms of dissent. ${ }^{72}$

63 Erica Chenoweth, 'Trends in Nonviolent Resistance and State Response: Is Violence Towards Civilian-Based Movements on the Rise?', Global Responsibility to Protect, 9/1: 86-100 (2017). p. 92.

64 Sabine C. Carey, 'The Use of Repression as a Response to Domestic Dissent', Political Studies, 58/1:167-186 (2010), p. 177.

65 Uzonyi, 'Domestic Unrest, Genocide and Politicide', p. 324.

66 Ibid., p. 323 .

67 Ibid., pp. 324, 329-30.

68 Krain, 'State-Sponsored Mass Murder', pp. 348-49.

69 Ibid., p. 354.

70 Chenoweth, 'Trends in Nonviolent Resistance and State Response', p. 90.

71 Jay Ulfelder, 'Forecasting Onsets of Mass Killing' (Unpublished Manuscript, 2012), p. 10, http://politics.as.nyu.edu/docs/CP/1293/Forecasting_Onsets_Mass_Killing.pdf, accessed 1 June 2018.

72 Erica Chenoweth, Evan Perkoski, and Sooyeon Kang, 'State Repression and Nonviolent Resistance', Journal of Conflict Resolution, 61/9: 1950-1969 (2017), p. 1960. 
In sum, the evidence suggests that some types of nonviolent movements do increase the risk of atrocities, but not as much as violent threats against a government, and that nonviolent movements do not have a significant impact on the chances of mass atrocity onset. Nonetheless, one might then conclude that nonviolent mass protests should therefore be avoided because there is some evidence that nonviolent resistance increases the risk of violence and atrocities. Despite some less than clear sourcing for their claims, it turns out that the main mistake of authors of some key atrocity prevention documents concerning nonviolent resistance was not in the empirical analysis, but in their subsequent logical analysis. The conclusion that nonviolent movements should always be avoided does not follow from the finding that nonviolent resistance may increase the risk of atrocities compared with doing nothing.

Even if nonviolent protests increase the risk of atrocities compared with no resistance to a government's autocratic rule, they still might be preferable to alternative, violent strategies because the latter might have a greater increase of the risk of atrocities and might be less likely to achieve just aims. Activists may be unwilling to back down. The politically feasible options may be to wage resistance violently or nonviolently (or both). Of course, in addition to this comparison, activists should consider whether it is a good idea to wage any form of resistance at all (as well as other means of achieving their just aims). Thus, we should ask the following questions, drawing on widely accepted moral principles. First, which violent or nonviolent strategies would be necessary and proportionate, even when a regime unjustly harms innocent protesters? Second, even if there is some chance that nonviolent democratic movements might indirectly result in an atrocity, might they still be the best option available?

This second question might seem odd. To see why it is not, imagine the following hypothetical situation. Suppose a wave of democratisation protests breaks out somewhere. Imagine that revolutionaries and foreign government meet to decide how to move ahead. Suppose that the revolutionaries are committed to democratisation and will not back down: the choice they have given themselves is between armed resistance and nonviolent resistance. Stopping all action and returning to daily life is another option. Imagine there is a country where democratic activists are planning a movement to replace current leaders with democratic ones. Suppose that if they use nonviolent methods, the best estimate of the number of innocent people who will be killed is around 50o. Assume that this could constitute a crime against humanity. Suppose a violent revolt is expected to result in 5000 deaths of innocent civilians. Furthermore, suppose that if a regime were left in place it would unjustly kill an estimated 100 people per year for the foreseeable future, whereas a new 
democratic government would kill unjustly 10 people per year. What is the best option? I argue that nonviolent methods are the better option, compared with violent revolt as well as with doing nothing under these circumstances and given what we know about the likely chances of success of various means of democratisation. This is because the nonviolent option has the highest chance of resulting in both the good of democracy and the lowest expected number of deaths of innocents over the medium to long term (specifically, $>5$ years).

Another concern is that nonviolent resistance is least likely to be effective against those regimes that are most willing to commit atrocities. There are three responses to this concern. First, there are at least some examples of nonviolent movements playing a pivotal role in ousting leaders who have already committed terrible atrocities, and those leaders leaving power without committing additional atrocities against the protesters. Slobodan Milošević is one example. Even though NATO intervened militarily against his regime twice, he remained in power after each military operation. Yet mass nonviolent protests, organised by leaders of Otpor, played a vital role in ousting him from power in 2000. Part of the reason they succeeded, according to one of Otpor's leaders, is because they convinced the police not to use violence against the protesters. ${ }^{73}$ Second, even if repression of nonviolent protest leads to an atrocityimagine 800 deaths of protesters constitutes a crime against humanity-it may be preferable to taking up arms because it is still statistically less likely to result in even worse atrocities, and more likely to result in democracy. Third, nonviolent protests should not be seen as a panacea. Presumably there are some cases where the chances of success are too low to make violent or nonviolent action advisable. Some state or nonstate actor would likely commit horrific massacres against nonviolent protesters. Sometimes the least worst option may be to try to survive under a non-democratic regime without collectively agitating for democratisation.

Given the evidence I present above and the ethical precepts from just war theory, it is preferable in an average situation to maintain nonviolent resistance than it is to take up arms. This is because on average nonviolent resistance is more likely to achieve democracy and less likely provoke the government to commit atrocities in response to a challenge to its power. Nonviolent resistance should be a standard policy option, especially when considered as an alternative to war and violent struggle for democratisation. 


\section{Is Nonviolent Resistance Overly Demanding?}

Even if the preceding argument is correct, nonviolence resistance as an atrocity prevention policy faces an important objection, namely that it imposes an unfairly demanding burden on innocent individuals by requiring them to refrain from exercising their right to use defensive violence when they or others are unjustly attacked. The objection runs as follows. Everyone has a right to bodily integrity (UDHR 3). There are certain things one can permissibly do in defence of this right. One can retreat and block blows. But one can also use defensive force against an unjust attacker if it is necessary and proportionate to avert the unjust threat. The objection is that nonviolent resistance is problematic because it requires an overly burdensome curtailment of the violent, defensive means of exercising and protecting the vital human right of bodily integrity.

There are two replies to this objection. The first involves what Wesley Hohfeld calls a 'power. ${ }^{74}$ These are second order rights that allow the right holder to modify the first order right. ${ }^{75}$ For instance, one can waive, annul, or transfer to another person some rights. In this case, the relevant second order right is waiving. That is, one can decide to waive one's right to violent self or other defence. ${ }^{76}$ Waiving a right involves consensually refraining from using a right for some period of time. Just as one can waive the right against being attacked in situations like boxing and wrestling, one can decide to not use one's right to violent self-defence in situations where one is working for political reform. Nonviolent resistance is not overly burdensome because individuals can consent to waive their right to violent self-defence. Of course, it does not make it permissible for the state (or any other actor) to harm or kill any nonviolent protester because one is not waiving one's right to bodily integrity. ${ }^{77}$ Rather, a person is waiving one means of protecting that right. This would permit the use of nonviolent action as a means to achieve other goals even with the knowledge that state security forces are likely to harm some innocent nonviolent protesters.

Another reply to the objection focuses on proportionality. It holds that violent means of achieving a just cause are less likely to be proportionate than are

74 Wesley Newcomb Hohfeld, 'Some Fundamental Legal Conceptions as Applied in Judicial Reasoning', The Yale Law Journal, 23/1: 16-59 (1913), pp. 44-54.

75 Leif Wenar, 'The Nature of Rights', Philosophy \& Public Affairs, 33/3: 223-252 (2005), pp. $230-37$.

76 Finlay, Terrorism and the Right to Resist, p. 93.

77 Ibid. 
nonviolent means and that therefore activists working for a just cause are not only permitted to use nonviolent means but generally must do so, given that violent means are likely to be disproportionate. A widely accepted constraint on the use of force as a means of self and other defence is that it must be proportionate (as well as necessary, but I will focus on proportionality here). It is useful here to differentiate 'narrow' and 'wide' proportionality, as Jeff McMahan does. ${ }^{78}$ Narrow proportionality assesses whether a response to the individual or individuals who are liable to defensive harm is permissible. It roughly requires that the harm inflicted on the liable attacker be less than or commensurate with the unjust threat. ${ }^{79}$ Liability to defensive harm means that someone has forfeited to some degree at least one right (the right to bodily security) as someone is posing a threat. (The reasons why and how someone becomes liable are interesting and contested merely posing a threat, some degree of responsibility for posing the threat, whether the threat is subjectively or objectively unjust, and so on\}, but need not concern us here.) For instance, if someone is threatening to stomp on your foot, it would be disproportionate to shoot and kill him with a gun because the small threat to you is incommensurate with the great harm to the attacker. If you could not easily move your foot, it might be permissible to push the attacker so that he becomes unbalanced and must step back, thereby preventing harm to your toe. Wide proportionality involves potential harm to innocents. ${ }^{80}$ Wide proportionality can involve the response from the victim or from the attacker. For instance, before a victim shoots at an unjust attacker, she must consider whether a stray bullet may hit an innocent bystander. But she must also consider the response of other government soldiers in response to a violent means of justified self-defence. Generally, the proportionality constraint on the defensive use of force only permits violent defensive action if it is likely to meet both wide and narrow proportionality. Given the empirical literature on likely outcomes of violent and nonviolent means of say agitating for democratic government, wide proportionality is especially relevant here. It might be permissible for a protester to shoot and kill a soldier who has unjustly opened fire on peaceful protesters, but if the regime's forces then slaughter a great number of innocent civilians because of the (just) use of force by the protester, such force might render the narrowly proportionate use of force against the soldier impermissible because the actions of the regime could be widely disproportionate.

\footnotetext{
78 McMahan, Killing in War, pp. 20-21.

79 Ibid., pp. 20-21.

8 o Ibid., p. 21.
} 
Christopher Finlay describes what he terms 'the proportionality paradox'. ${ }^{81}$ He means by this that 'some regimes will attempt to curb resistance by imposing costs sufficient to render resistance by all available avenues disproportionate.' ${ }^{2}$ In other words, what might otherwise be permissible (nonviolent or violent) actions could be rendered impermissible because of the harsh and specifically widely disproportionate response that a regime would inflict in response to the nonstate actions. Given what we know about the likely outcomes of violent and nonviolent means of attempting democratisation, violent means are much more likely to provoke violent crackdowns that would render them impermissible compared with nonviolent options.

\section{Nonviolent Resistance, R2P and State Sovereignty}

Furthermore, some may raise the worry that some proponents of $\mathrm{R} 2 \mathrm{P}$ have voiced concerning the armed intervention against Libyan dictator Muammar Gaddafi. They argue that because targeting Gaddafi's forces overstepped the UN Security Council mandate, it weakened the R2P norm, and used the prevention of mass atrocities as pretext for regime change..$^{83}$ As Ramesh Thakur notes in a discussion of the armed humanitarian intervention in Libya, 'All the BRICS countries (Brazil, Russia, India, China, South Africa) objected strongly to the shift from the politically neutral posture of civilian protection to the partial goal of assisting the rebels and pursuing regime change. ${ }^{84}$ Similarly, critics of regime change could object to attempting to replace autocratic leaders with democratic leaders and institutions because they argue that state sovereignty matters, even though it can be forfeited under certain conditions when mass atrocities are ongoing. There are several responses to this objection.

81 Finlay, Terrorism and the Right to Resist, pp. 151-54.

82 Ibid., p. 153 .

83 Regime change may be more closely connected to R2P than may be politically convenient. Alex Bellamy presents historical data showing that government-committed atrocities that resulted in at least 5,000 deaths end most often when leaders themselves decide to end them, but 'some degree of regime change' is the second most prevalent way for them to end, constituting approximately $40 \%$ of the cases. See Alex Bellamy, 'The Responsibility to Protect and The Problem of Regime Change' in Don E. Scheid (ed.), The Ethics of Armed HumanitarianIntervention, (Cambridge:Cambridge University Press, 2014), pp. $168-69$.

84 Ramesh Thakur, 'R2P after Libya and Syria: Engaging Emerging Powers', The Washington Quarterly, 36/2: 61-76 (2013), p. 70. 
First, as Welsh argues, preventing mass atrocities is inherently 'controversial.: ${ }^{85}$ I know of no way to avoid how contentious mass atrocity prevention efforts are in cases of attempted democratisation through nonviolent mass movements or other means. Leaders may have to make trade-offs in building political support for R2P and in implementing strategies like nonviolent resistance that may be the most effective means of prevention.

This does not mean that one should easily dismiss objections such as the ones raised by representatives of the BRICS, and I offer several responses to their concerns here. The important questions are to what extent foreign intervention constitutes coercion and when does it violate state sovereignty. There are not easy or clear lines, except in extreme cases. Domestic nonviolent protests without significant foreign involvement would not violate state sovereignty because the protests are domestic, by definition. Nevertheless, international state and nonstate actors could play a role in promoting nonviolent movements through educational campaigns, peer-to-peer learning, financial support, etc. There is a wide continuum of foreign influence, from the non-coercive example of reading Gene Sharp's manual on nonviolent revolt that was reportedly popular in Egypt during the Arab Spring, ${ }^{86}$ to peer-to-peer learning, ${ }^{87}$ to the potentially more contentious foreign funding of nonviolent groups. ${ }^{88}$

Foreign support of peaceful, nonstate groups highlights a limitation to the state-centric, three pillar model of R2P. ${ }^{89}$ The literature suggests that nonviolent action may be a useful way to avoid atrocities when attempting democratisation, but Pillars One and Two focus, respectively, on a state's domestic responsibilities and on the international community assisting a state to avoid atrocities. If it is possible to contribute to preventing atrocities by peacefully supporting nonstate actors before atrocities occur, state and nonstate leaders should consider how to incorporate this into, or revise, the three-pillar model. There are strong reasons to support preventing atrocities, rather than only being able to interfere in a state's domestic affairs without the leader's consent after they have already started, as politically contentious as this would

85 Welsh, 'The Responsibility to Prevent', p. 217.

86 Janine Di Giovanni, 'Gene Sharp, Theorist of Power', The New York Times, 3 September 2012, http://www.nytimes.com/2012/og/og/t-magazine/gene-sharp-theorist-of-power.html, accessed 1 June 2018.

87 David D. Kirkpatrick and David E. Sanger, 'Egyptians and Tunisians Collaborated to Shake Arab History', The New York Times, 13 February 2011, http://www.nytimes.com/2011/o2/14/ world/middleeast/14egypt-tunisia-protests.html?pagewanted=all, accessed 1 June 2018.

88 Chenoweth and Stephan, Why Civil Resistance Works, p. 54.

89 Ban, 'Implementing the Responsibility to Protect.' 
be. Just as there are varying degrees of military intervention (supplying arms, training rebels, covert action, overt action, etc.), there are various means of supporting nonviolent mass protests (as mentioned above). Presumably some types of support would be more acceptable to certain state leaders than others. Although this would not directly address the objection, state leaders could also consider covert means to support nonviolent groups. ${ }^{90}$ That said, there are some things the international community can do overtly within the threepillar model. The international community could encourage and incentivise states to refrain from committing atrocities against peaceful groups agitating for change under Pillar Two, and use higher levels of support such as foreign funding to groups that use nonviolent methods if and when states begin committing atrocities against protesters who have legitimate aims.

Because most types of nonviolent protests decrease the chances of atrocity compared with most violent means of revolution on average, nonviolent protest actually decreases the chance that states would use force to stop an ongoing atrocity compared with domestic sources of violent means of democratisation. Rather than being inconsistent with R2P, such peaceful options could be seen to be what states themselves agreed to in $2005 .{ }^{91}$ If violent foreign intervention is generally worse and more controversial than nonviolent foreign influence, and foreign support for nonviolent civil resistance decreases the chances of foreign armed intervention, this suggests another reason why nonviolent movements are often preferable to violent ones.

In addition to the theoretical bases for action, there are several practical benefits to nonviolent mass protests compared with other policy options. These include lower economic and political costs to foreign actors interested in avoiding atrocities (and promoting democracy) compared with other methods. As Benjamin Valentino argues, armed humanitarian intervention can be extremely expensive compared with other ways of addressing atrocities..$^{92}$ It is generally monetarily cheaper to prevent atrocities than to expend resources to attempt to stop and rebuild after them. Sending in the military to end atrocities once they begin can be politically costly too. It is in the international community's interests in general to avoid the refugees and IDPs that war and atrocities create, because of their political, economic, and moral costs.

$90 \quad$ Heather M. Roff, 'Covert Actions and the Responsibility to Protect', Global Responsibility to Protect, 7/2: 167-89 (2015).

91 United Nations, 'World Summit Outcome Document', paras. 138-139.

92 Benjamin A. Valentino, 'The True Costs of Humanitarian Intervention: The Hard Truth About a Noble Notion', Foreign Affairs, 9o/6: 60-73 (2011). 
There are additional reasons why foreign actors should also favour nonviolent movements. Using data from successful revolutions from 1955 to 2004, Nam Kim finds that revolutionaries who gain power through violence are more likely to commit mass killings than are leaders who gain power by constitutional methods. ${ }^{93} \mathrm{Kim}$ also finds some evidence that violent revolutionary leaders are more likely than nonviolent leaders to commit mass killings. ${ }^{94}$ Uzonyi also finds that violent revolutionary leaders who successfully take power have increased risks of committing politicide..$^{95}$ Of course, all leaders should avoid atrocities. But these findings have important implications as to whether external actors should support groups that use violent or nonviolent means.

\section{Conclusion}

By emphasising the risks of nonviolent resistance and thereby excluding nonviolent resistance from the atrocity prevention policy toolbox, especially as an alternative to violent resistance, some authors of key atrocity prevention documents promote the opposite of what they intend. Policy documents should include all politically realistic options that can decrease the risk of atrocities. The argument I present shows that when mass atrocity prevention is appropriately understood as selecting politically feasible policies that will likely decrease the risk of atrocities, nonviolent action can play a critical role in atrocity prevention. Both domestic and international actors interested in mass atrocity prevention and R2P should revise their standard toolbox in order to include nonviolent resistance. Domestic actors should be interested in nonviolent resistance because of its comparative chance of success and the decreased risks of atrocities. External actors focused on promoting democracy and atrocity prevention should be interested in it for strategic as well as moral reasons. International actors should support and encourage nonviolence among those who are agitating for democracy and trying to achieve other ends, at least to the extent this is compatible with R2P, and possibly even if it goes beyond the three-pillar understanding of $\mathrm{R} 2 \mathrm{P}$ if on balance it is likely to save a greater number of lives of innocents than other options. This support and encouragement could take multiple routes including providing education and training

93 Nam Kyu Kim. 'Revolutionary Leaders and Mass Killing', Journal of Conflict Resolution, 62/2: 289-317 (2018).

94 Ibid., pp. 306-308.

95 Gary Uzonyi, 'Civil War Victory and the Onset of Genocide and Politicide', International Interactions, 41/2: 365-391 (2015). 
for leaders of revolutionary movements, facilitating peer-to-peer learning by for instance providing financial support for leaders of previous nonviolent struggles to travel to and educate emerging non-states leaders leading democratic revolutions, refraining from arming rebels, and so on. Although it is not a panacea, and should be used cautiously given the risks it carries regarding provoking atrocities, including nonviolent resistance in the mass atrocity toolbox could increase the chance of saving lives and avoiding atrocities.

\section{Acknowledgements}

For their helpful feedback on earlier drafts of this paper, I would like to thank the anonymous reviewers, Tessa Alleblas, Samir Naser, Edward Newman, Karambu Ringera, Geoffrey Swenson, James Pattison, Savita Pawnday, Scott Wisor, and the organisers and participants at the University of Leeds workshop on R2 P on 13-14 October 2016. I am grateful to Netherlands Organization for Scientific Research (NWO) (grant W 08.400.121) and The Hague Institute for Global Justice for support on this paper. Any mistakes are solely my responsibility. 